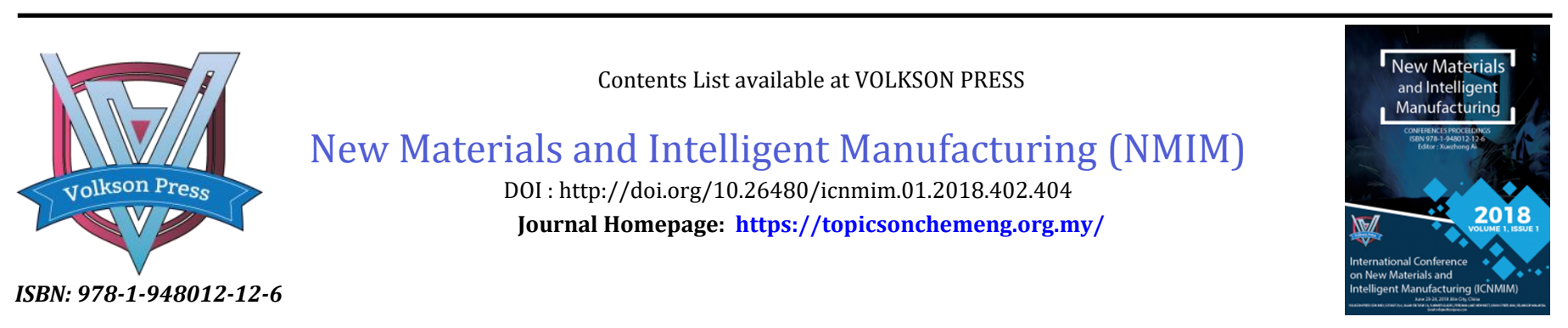

\title{
EFFECT OF MEA HOT-PRESSING ON THE PERFORMANCE OF DIRECT METHAND FUEL CELLS
}

\author{
Donghui Shen, Hailun Chen, Aihua Tian* \\ Jilin Institute of Chemical Technology, Chengde Street, Jilin City, China \\ *Corresponding Author E-mail: tah0077@hotmail.com
}

This is an open access article distributed under the Creative Commons Attribution License, which permits unrestricted use, distribution, and reproduction in any medium, provided the original work is properly cited.

\section{ARTICLE DETAILS}

\section{Article History:}

Received 26 June 2018

Accepted 2 July 2018

Available online 1 August 2018

\section{ABSTRACT}

MEA based on Nafion 115 has been prepared with GDL-based method for direct methanol fuel cell applications. The results of unit cell tests show that different temperature and pressure of hot-pressing during MEA preparation presents different polarization curve. Optimization of temperature and pressure during hot-pressing can effectively improve the performance of direct methanol fuel cells.

\section{KEYWORDS}

DMFC, MEA, hot-pressing.

\section{INTRODUCTION}

Direct methanol fuel cell (DMFC) is a kind of fuel cell based on proton exchange membrane (PEM) technology using methanol solution as fuel, while oxygen or air as oxidant. It has a number of advantages such as small volume, light weight, compact structure, high energy density, convenient storage and carrying etc... It is suitable for various potential applications including stationary and portable applications. Based on a study, it can meet the increasing demand of high energy consumption of portable electronic devices such as mobile phone, notebook computer, video camera, personal digital assistant and medical device system as well as spacecraft power supply, microelectronic mechanical system power and so on $[1,2]$. In recent years, it has become a hot research topic in the world and has been considered as a highly promising power source.

Membrane electrode assembly (MEA) is the core component of direct methanol fuel cell. It is made up of polymer electrolyte membrane, catalytic layer and diffusion layer. The conductivity and mass transfer ability of the membrane electrode are very important for the fuel cell reaction. Therefore, the preparation of MEA has been the focus of the research and development of DMFC.

According to research, there are two main methods widely used to fabricate the MEA, that is, gas diffusion layer (GDL)-based method and membrane-based method [3-6]. The hot-pressing is a key step in the GDLbased method of MEA fabrication. The purpose of this work is to investigate the performances of MEAs that prepared by different hotpressing temperature and pressure.

\section{EXPERIMENTAL}

\subsection{Preparation of Membrane Electrode Assembly (MEA)}

Based on a study, the proton exchange membranes used in this experiment are all Nafion 115 (DuPont, USA). All membranes should be pretreated before using, which means that they were boiled at $80^{\circ} \mathrm{C}$ in $3 \%$ $\mathrm{H}_{2} \mathrm{O}_{2}$ solution, deionized water (DI) $0.5 \mathrm{M} \mathrm{H}_{2} \mathrm{SO}_{4}$ solution and again in DI water, each for 1 hour firstly [7]. Then the membranes were preserved in the deionized water for reserve. Before using, the membranes were removed from the deionized water, and were dried naturally in the air for no less than 4 hours.

MEAs were fabricated with home-made electrodes. The catalyst of anode and the cathode used supported Pt-Ru/C $(40 \% \mathrm{Pt}$ and $20 \% \mathrm{Ru}$ on Vulcan
XC-72R Carbon, ca. atomic ratio 1:1, from Johnson Matthey) and supported $\mathrm{Pt} / \mathrm{C}(60 \% \mathrm{Pt}$ on Vulcan XC-72R Carbon, from Johnson Matthey) respectively. The catalyst inks were prepared by mixing catalyst, distilled water, Nafion solution and ethylene glycol together. The mixtures were stirred for about $30 \mathrm{~min}$ and sonicated for at least $1 \mathrm{~h}$. based on a research, after sonication, the catalyst ink became quite viscous, then the catalyst slurry was evenly sprayed on carbon paper (GDL 30BC) with a spray gun (GP-2, Fuso Seiki, Japan) [8,9]. The load of the catalyst for the anode and cathode are all $3 \mathrm{mg} . \mathrm{cm}^{-2}$.

The proton exchange membrane was sandwiched between two electrodes mentioned above and the resulting membrane electrode assembly (MEA) was then hot-pressed for 5 minutes at different temperatures $\left(140^{\circ} \mathrm{C}\right.$, $\left.150^{\circ} \mathrm{C}, 160^{\circ} \mathrm{C}, 170^{\circ} \mathrm{C}\right)$ and different pressures $\left(40 \mathrm{kgf.cm}^{-2}, 80 \mathrm{kgf.cm}^{-2}\right)$, thus fabrication of MEA under different hot-pressing conditions finished. The hot-pressing duration in our work was not included and it was maintained at $5 \mathrm{~min}$, which is enough to get an MEA for unit cell in the short-term operation [10]. All MEAs had an active area of $2 \mathrm{~cm} \times 2 \mathrm{~cm}$.

\subsection{Performance Test of Unit Cell}

The MEA was coupled with gas-sealing gaskets and fixed between bipolar plates and assembled into unit cell. The performance of unit cell was tested by a single cell test station. In this experiment, the anode was supplied with $2 \mathrm{M}$ methanol at a flow rate of $0.6 \mathrm{~mL} \cdot \mathrm{min}^{-1}$ while the cathode was supplied with non-humidified oxygen at a flow rate of $100 \mathrm{~mL} \cdot \mathrm{min}^{-1}$. In order to ensure that the concentration of methanol is constant, the methanol solution is used in a single flow through the cell without recirculation when the cell performance is tested.

The performance tests of unit cell operated at $30^{\circ} \mathrm{C}, 60^{\circ} \mathrm{C}$ and $80^{\circ} \mathrm{C}$ were carried out in this experiment. The methanol solution and oxygen were heated to the same temperature as the cell body by passing through a preheating device before entering the cell. All the temperatures of methanol solution, oxygen and cell body were controlled by the precise temperature control instrument. The unit cells performances were characterized by polarization curves which were obtained using an electronic loader by varying the current. All the experimental results were obtained under steady-state conditions.

\subsection{Physical Characterizations of MEA}

Scanning electron microscopy micrographs (FE-SEM, Hitachi S-4300) 
were taken to obtain information of the cross-sectional view of MEA that fabricated under the studied hot-pressing conditions.

\section{RESULTS AND DISCUSSIONS}

\subsection{Effect of MEA Hot-pressing Pressure on Unit Cell Performance}

Figure 1 and Figure 2 showed the polarization curves for MEA fed with 2M methanol and oxygen at different operation temperatures, $30^{\circ} \mathrm{C}, 60^{\circ} \mathrm{C}$ and $80^{\circ} \mathrm{C}$. The figures compared two unit cells performances that used MEA hot pressed at temperature of $140^{\circ} \mathrm{C}$ and duration of $5 \mathrm{~min}$, with pressure of $40 \mathrm{kgf.cm}{ }^{-2}$ and $80 \mathrm{kgf.} \mathrm{cm}^{-2}$ respectively. For the MEA with hot-pressing pressure of $40 \mathrm{kgf.cm}{ }^{-2}$, maximum power density of $68 \mathrm{~mW} . \mathrm{cm}^{-2}$ was observed at $80^{\circ} \mathrm{C}$, and the MEA with hot-pressing pressure of $80 \mathrm{kgf.cm}^{-2}$ yielded maximum power density of $86 \mathrm{~mW} . \mathrm{cm}^{-2}$ at the same operation temperature. At the same hot-pressing temperature, the unit cell performance of MEA which prepared under higher pressure is better.

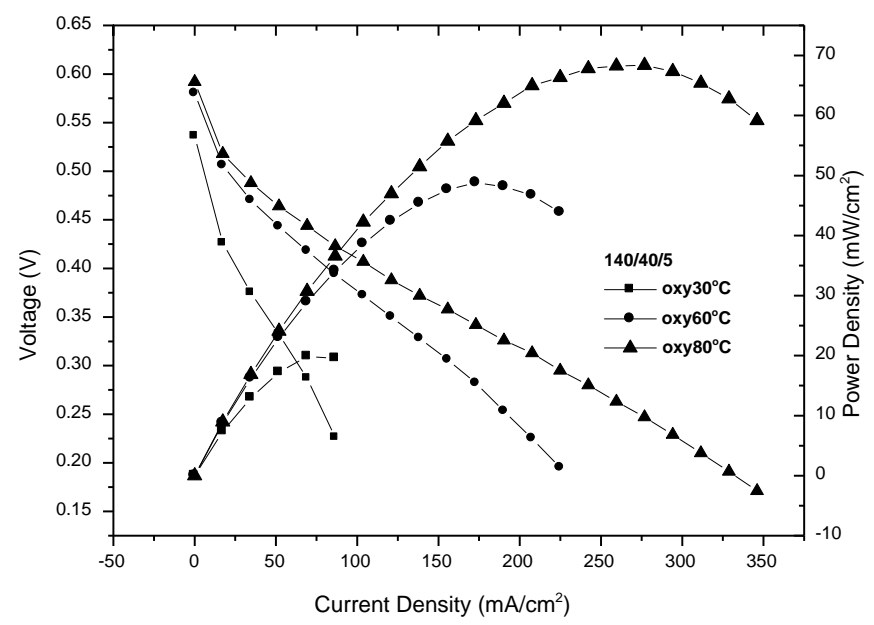

Figure 1: Polarization curves of unit cell based MEA hot-pressed under temperature of $140^{\circ} \mathrm{C}$, pressure of $40 \mathrm{kgf.cm}{ }^{-2}$ with operation temperature of $30^{\circ} \mathrm{C}, 60^{\circ} \mathrm{C}$ and $80^{\circ} \mathrm{C}$

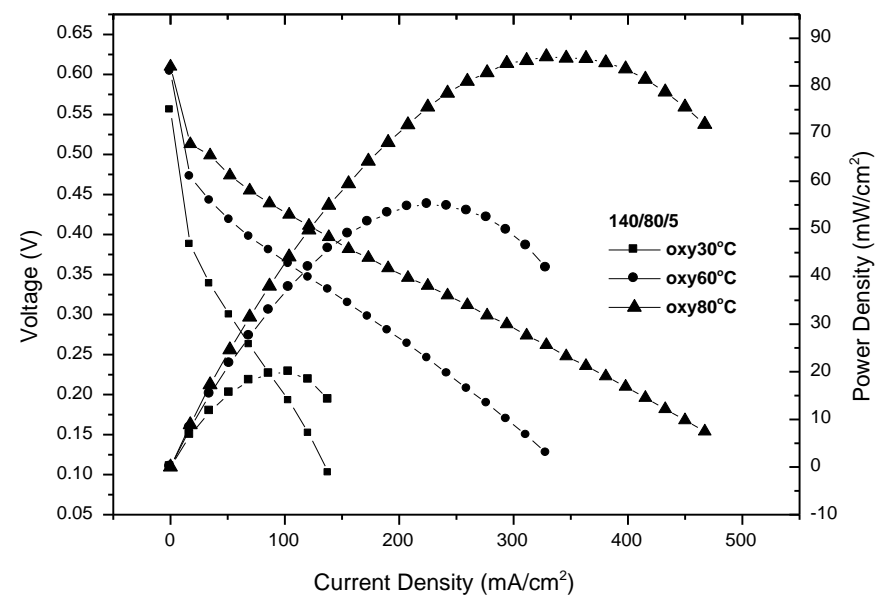

Figure 2: Polarization curves of unit cell based MEA hot-pressed under temperature of $140^{\circ} \mathrm{C}$, pressure of $80 \mathrm{kgf.cm}^{-2}$ with operation temperature of $30^{\circ} \mathrm{C}, 60^{\circ} \mathrm{C}$ and $80^{\circ} \mathrm{C}$.

The morphologies of the cross-sections of MEAs were investigated by SEM presented as figure 3 and figure 4 . The total electrode thickness decreases from $630 \mu \mathrm{m}$ to $585 \mu \mathrm{m}$ as the pressure applied during hot-pressing is increased.

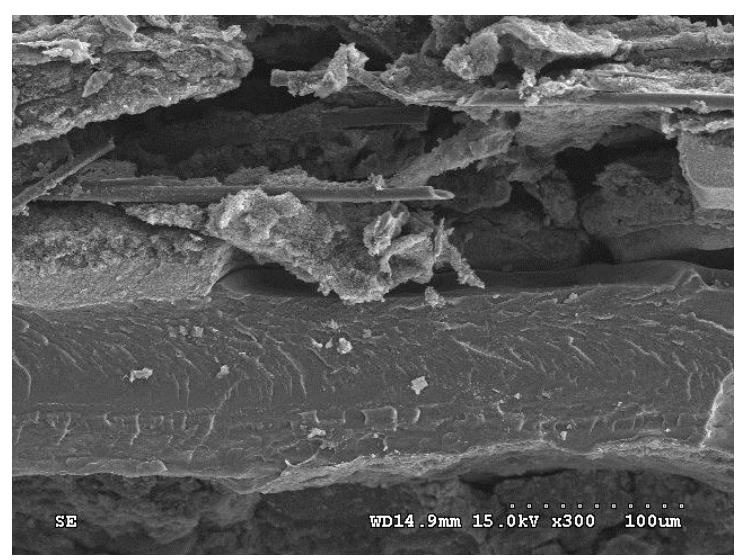

Figure 3: SEM image of MEA hot-pressed under temperature of $140^{\circ} \mathrm{C}$, pressure of $40 \mathrm{kgf.cm}{ }^{-2}$.

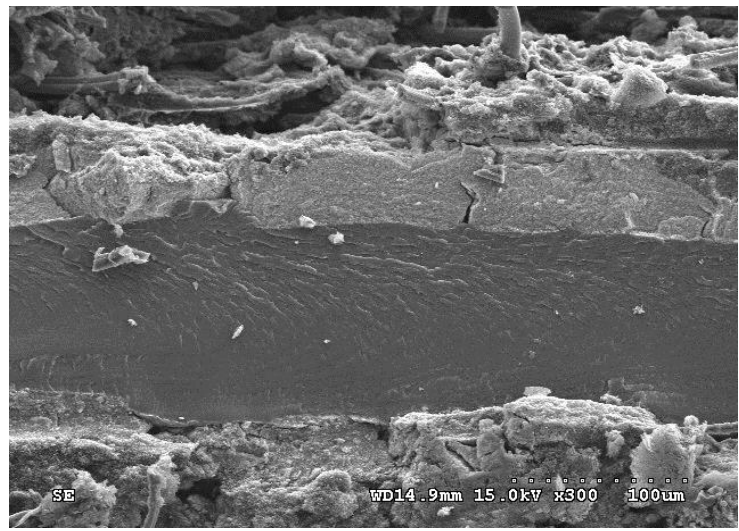

Figure 4: SEM image of MEA hot-pressed under temperature of $140^{\circ} \mathrm{C}$, pressure of $80 \mathrm{kgf.cm}^{-2}$.

\subsection{Effect of MEA Hot-pressing Temperature on Unit Cel Performance}

Figure 5,6,7 are the performance comparison of the MEAs prepared by hot-pressing at pressure of $40 \mathrm{kgf.cm}^{-2}$ and temperature of $150^{\circ} \mathrm{C}, 160^{\circ} \mathrm{C}$ $170^{\circ} \mathrm{C}$, with cell operation temperature of $30^{\circ} \mathrm{C}, 60^{\circ} \mathrm{C}$ and $80^{\circ} \mathrm{C}$. When hot pressed at the same pressure, it can be seen from the diagrams that the performance of unit cell based on MEA which hot pressed at $170^{\circ} \mathrm{C}$ is best. In the case of unit cell operated at a temperature of $80^{\circ} \mathrm{C}$, with all MEAs prepared by hot-pressing for 5 minutes at pressure of $40 \mathrm{kgf.cm}^{-2}$, the maximum output power density of MEAs with hot pressed at $140^{\circ} \mathrm{C}, 150^{\circ} \mathrm{C}$, $160^{\circ} \mathrm{C}$ and $170^{\circ} \mathrm{C}$ is $68 \mathrm{~mW} . \mathrm{cm}^{-2}, 78 \mathrm{~mW} . \mathrm{cm}^{-2}, 95 \mathrm{~mW} . \mathrm{cm}^{-2}$ and $100 \mathrm{~mW} . \mathrm{cm}^{-2}$ respectively.

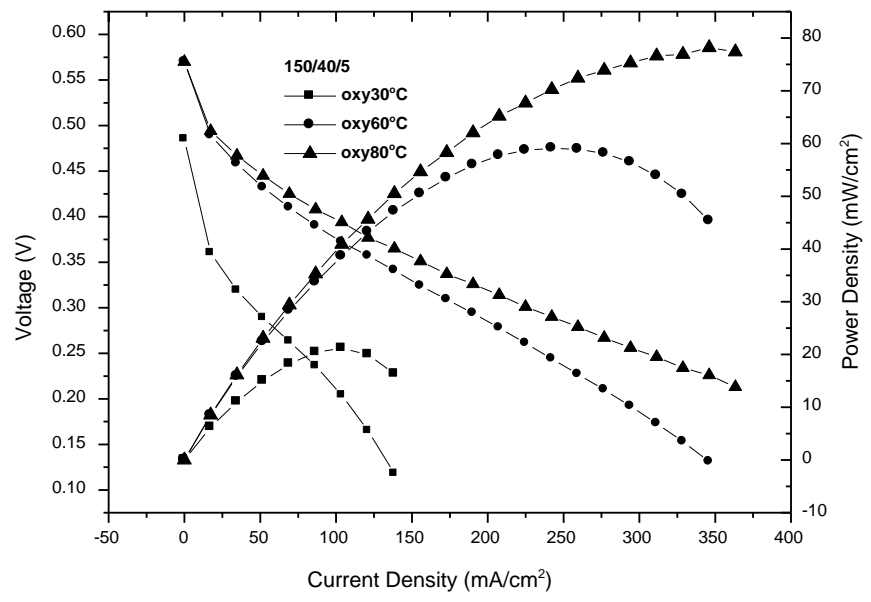

Figure 5: Polarization curves of DMFC unit cell based MEA hot-pressed under temperature of $150^{\circ} \mathrm{C}$, pressure of $40 \mathrm{kgf.cm}^{-2}$ with operation temperature of $30^{\circ} \mathrm{C}, 60^{\circ} \mathrm{C}$ and $80^{\circ} \mathrm{C}$. 


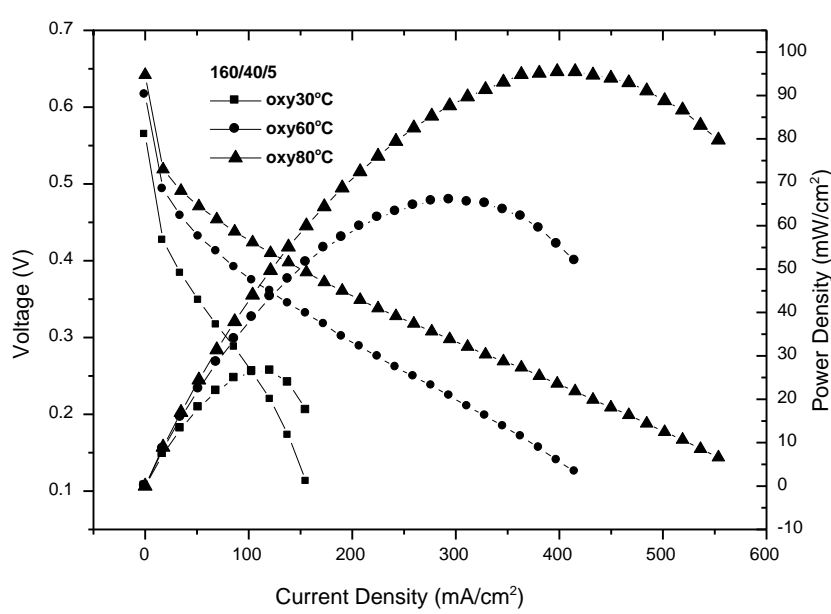

Figure 6: Polarization curves of DMFC unit cell based MEA hot-pressed under temperature of $160^{\circ} \mathrm{C}$, pressure of $40 \mathrm{kgf}_{\mathrm{cm}}-2$ with operation temperature of $30^{\circ} \mathrm{C}, 60^{\circ} \mathrm{C}$ and $80^{\circ} \mathrm{C}$

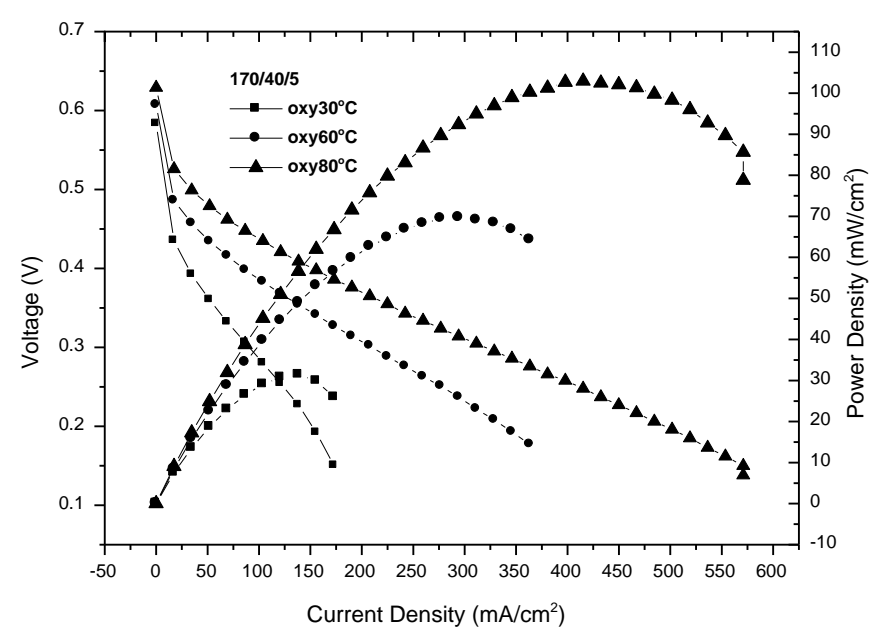

Figure 7: Polarization curves of DMFC unit cell based MEA hot-pressed under temperature of $170^{\circ} \mathrm{C}$, pressure of $40 \mathrm{kgf}_{\mathrm{cm}} \mathrm{cm}^{-2}$ with operation temperature of $30^{\circ} \mathrm{C}, 60^{\circ} \mathrm{C}$ and $80^{\circ} \mathrm{C}$.

According to a study, it was determined that the cell resistance increases when the applied pressure during MEA fabrication is greater than $20 \mathrm{kgf.cm}^{-2}$ [11]. However, our experiments showed that an increase in the temperature and pressure would increase the cell performance. The cell resistance of the MEA hot pressed at higher temperature and pressure would decrease because of the good contact between the electrodes and membrane. An increase of hot-pressing temperature and pressure increase the compression ratios of electrodes, which in turn raise the activating time required for cell to reach optimum performance.

\section{CONCLUSIONS}

The membrane electrode assembly of direct methanol fuel cell was prepared with GDL-based method by hot-pressing, and the performance of the membrane electrode assembly prepared under different hotpressing pressure and temperature was tested. The test results show that optimizing the preparation temperature and pressure of the membrane electrode can effectively improve the performance of DMFC.

\section{REFERENCES}

[1] Baldauf, M., Preidel, W. 1999. Status of the Development of a Direct Methanol Fuel Cell, Journal of Power Sources, 84, 161-166.

[2] Kamarudin, S.K. 2009. Overview on the Application of Direct Methanol Fuel Cell (DMFC) for Portable Electronic Devices, International Journal of Hydrogen Energy, 34, 6902-6916.

[3] nMeht, V., Cooper, J.S. 2003. Review and Analysis of PEM Fuel Cell Design and Manufacturing, Journal of Power Sources 114, 32-53.

[4] Frey, T., Linardi, M. 2004. Effects of Membrane Electrode Assembly Preparation on the Polymer Electrolyte Membrane Fuel Cell Performance, Electrochimica Acta, 50, 99-105.

[5] Daud, W.R.W. 2004. Performance optimisation of PEM fuel cell during MEA fabrication, Energy Conversion and Management, 45, 3239-3249.

[6] Song, S.Q. 2005. Direct Methanol Fuel Cells: The Effect of Electrode Fabrication Procedure on MEAs Structural Properties and Cell Performance, Journal of Power Sources, 145, 495-501.

[7] Dyer, C.K. 2002. Fuel Cells for Portable Applications, Journal of Power Sources, 106, 31-34.

[8] nTian, A.H. 2008. Poly(1-vinylimidazole) /Pd-impregnated Nafion for Direct Methanol Fuel Cell Applications, Journal of Power Sources, 183, 17.

[9] Tian, A.H. 2009. Surface-modified Nafion Membrane by Trioctylphosphine-Stabilized Palladium Nanoparticles for DMFC Applications, Journal of Physics and Chemistry of Solids, 70, 1207-1212.

[10] Liang, Z.X. 2005. Microscopic Characterizations of Membrane Electrode Assemblies Prepared Under Different Hot-pressing Conditions, Electrochimica Acta, 53, 894-902.

[11] Zhang, J. 2007. Effects of Hot Pressing Conditions on the Performances of MEAs for Direct Methanol Fuel Cells, Journal of Power Sources, 165 (1), 73-81. 